\title{
Effect of Pre-harvest Foliar Application of Citric Acid, Malic Acid and Tryptophan on The Growth, Flowering and Post-harvest Vase Life of tuberose Plants (B) Effect of Pre-harvest Treatments on Post-harvest Vase Life
}

\author{
Nader A. El-Shanhorey ${ }^{1}$, Ashraf M Shehata ${ }^{2}$ and Rehab A. Soffar ${ }^{3}$ \\ 1 Department of Botanical Gardens Research - Antonuades, Horticultural Research \\ Institute, Agriculture Research Center, Alexandria, Egypt. \\ ${ }^{2}$ Department of Floriculture, Ornamental Horticulture and Landscape Design - Faculty \\ of Agriculture, Alexandria University, Alexandria, Egypt \\ Department of Ornamental Plants Research - Antonuades, Horticultural Research \\ Institute, Agriculture Research Center, Alexandria, Egypt. ${ }^{3}$
}

\begin{abstract}
Tuberose (Polianthes tuberosa L.), is one of the most famous cut flowers used due to its delicate fragrance and commercial demand, nevertheless, the vase life of the inflorescence declines rapidly at home. To overcome this problem an experiment was conducted to find a suitable pre-harvest foliar application which provides the longest vase life of tuberose. Three foliar applications were used in the form of malic acid, citric acid and tryptophan after planting the bulbs with concentrations of $(0,100,200$ and $300 \mathrm{mg} / \mathrm{L})$ for each chemical. Cut inflorescences were then placed into a standard vase solution containing $4 \%$ sucrose and $200 \mathrm{mg} / \mathrm{L}$ of salicylic acid. Results showed that malic acid at the concentration of $(300 \mathrm{mg} / \mathrm{L})$, significantly affected all the vegetative parameters tested with the highest vase life 12.00 and 12.33 days compared with the control (8.33 and 7.66 days). Malic acid also gave the highest total chlorophyll and carbohydrates in the inflorescences of tuberose as compared with the control.
\end{abstract}

Key word: Polianthes tuberosa - malic acid - citric acid - tryptophan - vase life.

\section{INTRODUCTION}

Tuberose (Polianthes tuberosa L.), spikes of ivory flowers are prized for their fragrance and has long been cherished for the aromatic oils extracted from its fragrant flowers. It is one of the most important bulbous ornamentals as a member of Agavaceae family.

Although tuberose has a high potential for a long vase life after harvesting, it declines rapidly at home. Tuberose inflorescences (spikes) bear (10-20) pairs of florets which open acropetally. Consumers' carelessness, including neither recutting stem ends nor changing the vase solutions are the major factors in reducing the vase life of cut flowers (Jowkar and Salehi, 2005). Vase life of cut tuberose flowers is usually short. Vase life of cut flowers is related to physiochemical processes and reduces through ethylene production and bacterial contamination in vase solution (Nowak and Rudnicki, 1990; van Doorn, 1997; Alaey et al., 2011). Short vase life is highly influenced by water loss and wilting during transpiration (van Doorn, 1997). Some treatments have been applied to increase the vase life of cut flowers by regulating water balance, distribution of assimilates, delaying senescence and blocking microbial agents (Alaey et al., 2011). Water balance is a main factor determining quality and longevity of cut flowers (da Silva, 2003). The major form of vascular occlusion is the blockage of xylem vessels by air emboli and 
microorganisms (van Doorn, 1997). Microorganisms, especially bacteria and fungi which grow in preservative solutions have a main adverse effect on the longevity of cut flowers. These microorganisms and their products plug the stem ends and restrict the water absorption, which reduce the longevity of cut flowers (van Doorn, 1997; Alaey et al., 2011). Microbes can also produce ethylene and secrete toxic compounds, also pectinase and accelerated senescence. Ethylene is major plant growth regulator related to senescence and its external application causes accelerated senescence (Reid and Wu, 1992). Several agents have been used in cut flower vase solution to extend vase life by improving water uptake (Lü et al., 2010).

Endogenous organic acids are the source of both carbon skelton and energy for cells and are used in the respiratory cycle and other biochemical pathways. Therefore, they can influence the vase life (da Silva, 2003). Malic acid is metabolized in plant mitochondria by reaction of malic emzyme, (Talebi et al., 2014). Malate is a common reserve anion playing a role in the plant vacuole as counter ion for $\mathrm{K}$ and $\mathrm{Ca}$. They also recorded that pre-harvest treatment of citric acid $(0.15 \mathrm{w} / \mathrm{v})$ increased the mean vase life of cut lilium flowers from 11.8 in control treatment to 14 days (Darandeh and Hadavi, 2012).

Eidyan et al. (2014) reported that citric acid spray $(0.1 \% \mathrm{w} / \mathrm{v})$ increased the vase life of tuberose cut flowers and increased the size of bulblets in a synergism with folia Fe. Citric acid is a six carbon organic acid, having a central role in citric acid cycle in mitochondria that creates cellular energy by phosphorylative oxidation reactions (Willis et al., 1981). Results on the application of citric acid on some physiological parameters in tuberose plants were promising (Ghazijahani et al., 2014). Tryptophan has an indirect role on the growth via auxin synthesis. Whereas it was suggested several alternative roles of IAA synthesis in plants, all starting from tryptophan, thus when tryptophan is supplied to most plant tissues, IAA was formed, (Taha, 2005).

The present study aimed to evaluate the effect of malic acid, citric acid and tryptophan as biostimulants, for increasing the ornamental performance of the tuberose post-harvest as well as to evaluate the use of these organic acid as pre-harvest foliar spray if they could increase the quality and the postharvest life of cut inflorescences of tuberose.

\section{MATERIALS AND METHODS}

The experiment was conducted in the Faculty of Agriculture, Alexandria University, Egypt during the two successive seasons of 2013 and 2014. Tuberose corms with average of $3.8 \mathrm{~cm}$ diameter and $70.0 \mathrm{~g}$ of fresh weight were obtained from a commercial farm at El-Kanater El-Khayreya. Corms were planted in a $30 \mathrm{~cm}$ plastic pot in sandy soil on the $13^{\text {th }}$ of May 2013 and 2014 in the two seasons, respectively.

The starting date of spraying was after sprouting of corms after 15 days from planting, in the two seasons of 2013 and 2014. Pre-harvest foliar sprays 
with citric acid $(0,100,200$ and $300 \mathrm{mg} / \mathrm{L})$, malic acid $(0,100,200$ and 300 $\mathrm{mg} / \mathrm{L})$ and tryptophan $(0,100,200$ and $300 \mathrm{mg} / \mathrm{L})$ were used as the following scheme:

- The first spraying was after sprouting 30 days at the $4^{\text {th }}$ of July.

- The second spraying was after sprouting 45 days at the $18^{\text {th }}$ of July.

- The third spraying was after sprouting 60 days at the $1^{\text {th }}$ of August.

- The fourth spraying was after sprouting 75 days at the $15^{\text {th }}$ of August.

The tuberose inflorescences were cut when two florets were opened per spike to follow up the vase life. Cut flowers were transported to the laboratory under dry conditions; they were recut before treatments to the length of $70 \mathrm{~cm}$, then put placed in a standard solution containing $4 \%$ sucrose and $200 \mathrm{ppm}$ salicylic acid in distilled water as was described by (Kazemi et al., 2012) in the first and second seasons, respectively. The vase life and floret opening of cut inflorescences were considered terminated when the number of senesced florets exceeded the number of opened ones, according to (Waithaka et al., 2001). Room temperature was $26^{\circ} \mathrm{C} \pm 1$ and total humidity was $70 \% \pm 2$. The following data were recorded after cutting the inflorescence:

1. Flowering characteristics:

- Number of flowers per spike.

- Inflorescence fresh weight (g).

- Inflorescence dry weight (g).

- Rachis length (cm).

2. Postharvest characteristics:

- Inflorescence vase life (days): calculated as the number of days from starting the vase life conditioning to the fading stage.

- Inflorescence fresh weight loss (g): Primary fresh weight of the inflorescence - Fresh weight of the inflorescence at the fading stage.

- Loss of flower fresh weight percentage (L.F.F.W): It was determined at the fading stage as the flowing formula as described by (Abou-Dahab et al., 2013).

$$
\text { L.F.F.W. }(\%)=\frac{\text { Initial fresh weight }- \text { Final fresh weight }}{\text { Initial fresh weight }} \times 100
$$

- Flower fresh weight / flower dry weight ratio (FWR): At the fading stage the flowers were oven dried at $75^{\circ} \mathrm{C}$ for 48 hours to get the flower dry weight (F.D.W.) then the fresh weight was divided on the dry weight as described by (Ibrahim, 2013).

$$
\mathrm{FWR}=\frac{\text { Fresh weight per plant }(\mathrm{g})}{\text { Dry weight per plant }(\mathrm{g})}
$$

\section{Chemical analysis:}

- Total chlorophylls in the spike leave: were determined in fresh spikes with SPAD instrument after five days as described by (Yadava, 1986).

- Total carbohydrates content in flower spike was determined as \% D.W. as described by (Dubios et al., 1956).

The layout of the experiment was a randomized complete blocks design $(\mathrm{RCBD})$, with 10 treatments and 3 replicates, each replicate consisted of 3 
plants. The data of the two seasons were statistically analyzed according to (Snedecor and Cochran, 1967) using L.S.D. at 0.05 of probability.

\section{RESULTS AND DISCUSSION}

\section{Flowering characteristics}

\subsection{Number of Flowers per Spike}

The data in Table (1) showed that the highest number of flowers per spike was obtained using malic acid at 300 ppm. ( 30.66 and 31.00 floret per spike in the first and second seasons, respectively). However, the lowest number of flowers per spike was found in the control 24.00 and 23.00 floret per spike in the first and second seasons, respectively. The increase in the number of flowers of spike sprayed with malic acid at 300 ppm supports the results reported by Jowkar and Salehi (2005) on Polianthes tuberosa.

Generally, the average increase of the number of flowers per spike sprayed with malic acid at $300 \mathrm{mg} / \mathrm{L}$ was 30.66 and 31.00 in the first and second seasons, respectively, the extent of any fall in the first grade (Class I) of export which is how far along flowers number per spike between 25-30 flowers, (GOEIC, 1988). Well, we found that the increase of the number of flowers per spike at control is 24.00 and 23.00 in first and second seasons, respectively, the extent of any fall in the second grade (Class $n$ ) for export which is how far along flowers number per spike between $20-25$ flowers (GOEIC, 1988).

\subsection{Cut inflorescence fresh weight (g)}

The heaviest inflorescence fresh weight was obtained using a preharvest application of malic acid at $300 \mathrm{ppm}$ (73.50 $\mathrm{g}$ in the first season and 200 $\mathrm{mg} / \mathrm{L} 79.31 \mathrm{~g}$ in the second season, respectively). While the lowest inflorescence fresh weight was found in the control treatment (45.91 and $43.51 \mathrm{~g}$ in the first and second seasons, respectively), as recorded in Table (1). Increases in the cut inflorescence fresh weight of flower as a result of malic acid treatments have been reported by Talebi et al. (2014) on Gazania rigens.

\subsection{Cut inflorescence dry weight $(g)$}

The cut inflorescence dry weight was the highest when malic acid was applied at $300 \mathrm{mg} / \mathrm{L}$ (13.87 $\mathrm{g}$ in the first season) and $200 \mathrm{mg} / \mathrm{L}$ malic acid in the second season (14.87 g), as was recorded in Table (1). The lowest inflorescence dry weight was recorded for the control (8.66 and $8.16 \mathrm{~g}$ in the first and second seasons, respectively). Those results were in agreement with those found by Talebi et al. (2014), who found that using $300 \mathrm{~g}$ of malic acid as foliar spray, significantly increased the dry weight of Gazania rigens L.

\subsection{Rachis length $(\mathrm{cm})$}

Results in Table (1) showed that the longest rachis length was obtained with $300 \mathrm{mg} / \mathrm{L}$ of malic acid treatment (30.00 in both first and second seasons), and the shortest one was obtained in the control $(24.33$ and $24.66 \mathrm{~cm}$ in the first and second seasons, respectively). A similar increase in the rachis length as a result of malic acid treatment was recorded by Talebi et al. (2014) on Gazania rigens. 
Malic acid significantly decreased the number of bacteria in vase solution and increased vase life compared to the control. Malic acid prevented vascular blockage by reducing the number of bacteria in vase solution. Bacteria in vase solution block vessels on the cut surface. Stem occlusion reduced the water uptake (van Meeteren, 1978). Some bacteria in vase solution produce ethylene, which induces vascular blockage and senescence. The use of other organic compounds such as salicylic acid, citric acid and ascorbic acid for increasing the vase life of cut flowers has been reported by some researchers (Darandeh and Hadavi, 2012; Jamshidi et al., 2012).

Table (1). Average of flowering characteristics of Polianthes tuberosa plants as influenced by citric acid, malic acid and tryptophan in the two seasons of 2013 and 2014.

\begin{tabular}{|c|c|c|c|c|c|c|c|c|c|}
\hline \multirow{2}{*}{\multicolumn{2}{|c|}{ Treatments }} & \multicolumn{2}{|c|}{$\begin{array}{c}\text { Number of } \\
\text { Flower per } \\
\text { Spike }\end{array}$} & \multicolumn{2}{|c|}{$\begin{array}{c}\text { Cut } \\
\text { inflorescence } \\
\text { fresh weight } \\
\text { (g) }\end{array}$} & \multicolumn{2}{|c|}{$\begin{array}{c}\text { Cut } \\
\text { inflorescence } \\
\text { dry weight } \\
\text { (g) }\end{array}$} & \multicolumn{2}{|c|}{$\begin{array}{c}\text { Rachis } \\
\text { Length }(\mathrm{cm})\end{array}$} \\
\hline & & 2013 & 2014 & 2013 & 2014 & 2013 & 2014 & 2013 & 2014 \\
\hline \multirow[t]{2}{*}{ Control } & $000 \mathrm{mg} / \mathrm{L}$ & 24.00 & 23.00 & 45.91 & 43.51 & 8.66 & 8.16 & 24.33 & 24.66 \\
\hline & $100 \mathrm{mg} / \mathrm{L}$ & 27.00 & 25.66 & 53.98 & 61.06 & 10.20 & 11.45 & 26.33 & 26.00 \\
\hline \multirow[t]{2}{*}{ Citric acid } & 200 & 27.00 & 27.33 & 59.43 & 56.12 & 11.22 & 10.52 & 26.66 & 26.33 \\
\hline & 30 & 28.66 & 28.00 & 66.81 & 71.76 & 12.61 & 13.46 & 27.66 & 27.33 \\
\hline & $100 \mathrm{mg} / \mathrm{L}$ & 29.00 & 27.33 & 65.13 & 73.95 & 12.29 & 13.87 & 29.00 & 28.66 \\
\hline \multirow[t]{2}{*}{ Malic acid } & $200 \mathrm{mg} / \mathrm{L}$ & 30.33 & 29.66 & 70.00 & 79.31 & 13.22 & 14.87 & 29.66 & 29.66 \\
\hline & $300 \mathrm{mg} / \mathrm{L}$ & 30.66 & 31.00 & 73.50 & 71.55 & 13.87 & 13.42 & 30.00 & 30.00 \\
\hline \multirow{3}{*}{ Tryptophan } & $100 \mathrm{mg} / \mathrm{L}$ & 24.33 & 23.33 & 47.09 & 42.72 & 8.89 & 8.01 & 24.33 & 25.00 \\
\hline & $200 \mathrm{mg} / \mathrm{L}$ & 25.66 & 24.66 & 55.12 & 54.94 & 10.40 & 10.30 & 25.00 & 25.33 \\
\hline & $300 \mathrm{~m}$ & 26.33 & 26.33 & 57.48 & 58.46 & 10.85 & 10.96 & 25.33 & 25.66 \\
\hline \multicolumn{2}{|c|}{ L.S.D. at 0.05} & 1.58 & 1.15 & 2.54 & 3.37 & 0.48 & 0.62 & 0.74 & 0.78 \\
\hline
\end{tabular}

\section{Postharvest characteristics}

\subsection{Inflorescence fresh weight loss $(\mathrm{g})$}

The data in Table (2) showed that the highest inflorescence fresh weight loss was found in the control (21.95 and $21.62 \mathrm{~g}$ in the first and second seasons, respectively), while the lowest inflorescence fresh weight loss was recorded using 300 ppm of malic acid (13.64 and $15.41 \mathrm{~g}$ in the first and second seasons, respectively). A similar decrease in the fresh weight loss as a result of malic acid treatment was recorded by Begri et al. (2014) on carnations cut flowers.

\subsection{Inflorescence vase life (days)}

The data presented in Table (2) showed that the highest value of vase life was found using 300 ppm malic acid treatment, which reached (12.00 and 12.32 days in the first and second seasons, respectively). However, the shortest vase life was obtained in the control recording 8.33 and 7.66 days in the first and second seasons, respectively. Our results seemed to be in agreement with the results of (Begri et al., 2014), on carnation. They found that a preservative solution containing $1 \mathrm{mM}$ malic acid and $4 \%$ ethane resulted in the longest vase life (11.1 days compared to 8.9 days in the control). It is also in agreement with Eidyan et al. (2014) on tuberose, Kazemi et al. (2012) on carnation and Zamani et al. (2011) on chrysanthemum cut flowers. 


\subsection{Loss of flower fresh weight (\%)}

The analysis of variance of the loss of flower fresh weight showed that the lowest flower fresh weight was obtained using a per-harvest foliar spray of malic acid at 300 ppm, it gave a length of 18.55 and $21.53 \%$ in the first and second seasons respectively, compared with the control which gave the highest loss of flower fresh weight (47.85 and $49.68 \%$ in the first and second seasons respectively), as was recorded in Table (2). It was previously concluded that malic acid improves the water balance of the cut tuberose flowers by control of the bacterial populations combined with reduction in water loss (Kazemi et al. 2010). In this work, our data supported earlier observation suggesting a regulating role of malic acid in water balance of cut flowers. We know that malic acid is an important osmoticum in guard cells that manages stomatal opening (Allaway 1973 and Zeiger 1983). Therefore, a direct role for malic acid in control of stomata function could be also possible in our experiment. Here, we can conclude that malic acid may have reduced the stomatal conductance in some way to yield such a controlling effect on fresh weight loss.

\subsection{Flower fresh weight / flower dry weight ratio}

The analysis of variance of the flower fresh weight / flower dry weight ratio showed that the lowest flower fresh weight / flower dry weight ratio was obtained using a per-harvest foliar spray with malic acid at $300 \mathrm{mg} / \mathrm{L}$, it gave 4.31 and $4.22 \%$ in the first and second seasons respectively, compared with the control which gave the highest flower fresh weight / flower dry weight ratio (2.75 and $2.67 \%$ in the first and second seasons respectively), as was recorded in Table (2). Data analysis showed that the effect of malic acid was significant on fresh and dry matter (Table 2). Results showed that malic acid in proper concentration increased dry matter of cut tuberose flowers. Positive effect of malic acid on fresh and dry matter is probably due to its antimicrobial properties. The present results are in agreement with those reported by Jamshidi et al. (2012) who showed that malic acid decreased microbe's population and increased dry weight.

Preferential solution uptake of cut flowers incubated in malic acid suggesting a possible decrease in xylem blockage due to reduced microbial growth and ethylene production. Positive effect of malic acid may be attributed to its antimicrobial activity that reduce bacterial population and resulted in increase the vessels conductivity and water uptake. Low water uptake by cut flowers is often due to occlusions located mainly in the basal stem end (He et al., 2006) and microorganisms and their decay products are a common cause of stem end blockage (van Doorn, 1997; Williamson et al., 2002). In many cut flowers, suppression of microbial growth in the vase solution results in delayed wilting (van Doorn, 1997). 
Table (2). Average of postharvest characteristics of Polianthes tuberosa plants as influenced by citric acid, malic acid and tryptophan in the two seasons of 2013 and 2014.

\begin{tabular}{|c|c|c|c|c|c|c|c|c|c|}
\hline \multicolumn{2}{|c|}{ Treatments } & \multicolumn{2}{|c|}{$\begin{array}{l}\text { Inflorescence } \\
\text { fresh weight } \\
\text { loss } \\
\text { (g) }\end{array}$} & \multicolumn{2}{|c|}{$\begin{array}{l}\text { Inflorescence } \\
\text { vase life } \\
\text { (day) }\end{array}$} & \multicolumn{2}{|c|}{$\begin{array}{l}\text { Loss of } \\
\text { flower fresh } \\
\text { weight } \\
(\%)\end{array}$} & \multicolumn{2}{|c|}{$\begin{array}{c}\text { Flower } \\
\text { fresh } \\
\text { weight / } \\
\text { flower dry } \\
\text { weight ratio }\end{array}$} \\
\hline & & 2013 & 2014 & 2013 & 4 & 2013 & 2014 & 2013 & 2014 \\
\hline \multirow[t]{2}{*}{ Control } & 000 ppm & 21.95 & 21.62 & 8.33 & 7.6 & 47 & 8 & 2.75 & 2.67 \\
\hline & $100 \mathrm{ppm}$ & 18.93 & 19.70 & 9.33 & 9.00 & 35.07 & 32.41 & 3.43 & 3.60 \\
\hline \multirow[t]{2}{*}{ Citric acid } & 200 ppm & 17.49 & 18.60 & 10.00 & 9.66 & 29.43 & 33.19 & 3.73 & 3.55 \\
\hline & 300 ppm & 18.44 & 17.99 & 10.33 & 10.33 & 27.60 & 25.11 & 3.83 & 3.99 \\
\hline \multirow{3}{*}{ Malic acid } & 100 ppm & 16.62 & 17.22 & 11.00 & 11.33 & 25.51 & 23.27 & 3.94 & 4.08 \\
\hline & 200 ppm & 15.74 & 16.43 & 11.33 & 11.66 & 22.48 & 20.65 & 4.10 & 4.18 \\
\hline & 300 ppm & 13 & & 12. & 12. & 18. & & 4.31 & 4.22 \\
\hline \multirow{3}{*}{ Tryptophan } & 100 ppm & 21.35 & 20.85 & 8.66 & 8.66 & 45.35 & 48.97 & 2.89 & 2.71 \\
\hline & $200 \mathrm{ppm}$ & 21.46 & 20.63 & 8.66 & 9.00 & 38.95 & 37.61 & 3.23 & 3.32 \\
\hline & 300 ppm & 20.53 & 20.01 & 9.66 & 9.66 & 35.68 & 34.28 & 3.40 & 3.49 \\
\hline \multicolumn{2}{|c|}{ L.S.D. at 0.05} & 1.47 & 1.43 & 0.93 & 0.73 & 2.25 & 2.50 & 0.12 & 0.13 \\
\hline
\end{tabular}

\section{Chemical analysis}

\subsection{Total chlorophyll content in the spike leaves}

The total chlorophylls content using (SPAD) unit was the highest using malic acid treatment at 300 ppm as shown in Table (3) (32.49 and 32.84 SPAD in the first and second seasons, respectively). The lowest chlorophyll content was obtained in the control 26.17 and 24.61 in the first and second seasons, respectively. These results are in agreement with those found by Darandeh and Hadavi (2012), who noted that a pre-harvest foliar application of malic acid surprisingly increased the chlorophyll content significantly in lilium cv. Brunello, Kazemi et al. (2012) on carnation and Zamani et al. (2011) on chrysanthemum cut flowers. (Darandeh and Hadavi, 2012) on Lilium revealed that malic acid increased the content of chlorophyll significantly than the control. These workers demonstrated that chlorophyll content was highest in cut flowers treated. Study of Kazemi et al. (2010) on the effect of malic acid on cut carnation flowers revealed that the total chlorophyll of flowers treated malic acid was the maximum compared to the other concentrations and control. The differences of chlorophyll content between treatments could be attributed to a various amount of malic acid taken up by cut flowers (Kazemi et al., 2010).

\subsection{Total Carbohydrate content in inflorescence (\% D.W.)}

As shown in Table (3) the highest total carbohydrates content was found using a pre-harvest foliar application of malic acid at $300 \mathrm{ppm}$ which gave 22.93 and $22.88 \%$ in the first and second seasons, respectively. While, the lowest total carbohydrates content was obtained in the control $(17.90$ and $18.78 \%$ in the first and second seasons, respectively). The results indicated that the carbohydrate content significantly increased as a result of using Malic acid. Treatment of $300 \mathrm{ppm}$ Malic acid solution significantly increased carbohydrate content in cut flowers. In agreement with our result, Kazemi et al. (2011) reported that treatment with Malic acid significantly extends the vase life. 
Table (3). Average of chemical constituents of Polianthes tuberosa plants as influenced by citric acid, malic acid and tryptophan in the two seasons of 2013 and 2014.

\begin{tabular}{llcc|cc}
\hline \multirow{2}{*}{ Treatments } & $\begin{array}{c}\text { Total Chlorophyll } \\
\text { content in the spike } \\
\text { leaves (SPAD) }\end{array}$ & \multicolumn{2}{c}{$\begin{array}{c}\text { Total Carbohydrates content } \\
\text { in inflorescence (\%) }\end{array}$} \\
\cline { 3 - 6 } & & $\mathbf{2 0 1 3}$ & $\mathbf{2 0 1 4}$ & $\mathbf{2 0 1 3}$ & $\mathbf{2 0 1 4}$ \\
\hline Control & $\mathbf{0 0 0} \mathbf{~ p p m}$ & 26.17 & 24.61 & 17.90 & 18.78 \\
\hline \multirow{3}{*}{ Citric acid } & $\mathbf{1 0 0} \mathbf{~ p p m}$ & 28.67 & 27.92 & 19.07 & 20.45 \\
& $\mathbf{2 0 0} \mathbf{~ p p m}$ & 28.67 & 29.10 & 19.44 & 21.07 \\
& $\mathbf{3 0 0} \mathbf{~ p p m}$ & 29.64 & 30.27 & 20.80 & 21.90 \\
\hline \multirow{3}{*}{ Malic acid } & $\mathbf{1 0 0} \mathbf{~ p m}$ & 30.37 & 31.25 & 21.53 & 22.24 \\
& $\mathbf{2 0 0} \mathbf{~ p m}$ & 31.13 & 32.08 & 21.87 & 22.78 \\
& $\mathbf{3 0 0} \mathbf{~ p p m}$ & 32.49 & 32.84 & 22.93 & 22.88 \\
\hline \multirow{3}{*}{ Tryptophan } & $\mathbf{1 0 0} \mathbf{~ p p m}$ & 27.20 & 25.96 & 18.29 & 18.22 \\
& $\mathbf{2 0 0} \mathbf{~ p p m}$ & 27.94 & 26.57 & 18.78 & 20.64 \\
& $\mathbf{3 0 0} \mathbf{~ p p m}$ & $\mathbf{2 8 . 3 7}$ & 27.43 & 19.07 & 20.76 \\
\hline \multicolumn{2}{c}{ L.S.D. at $\mathbf{0 . 0 5}$} & $\mathbf{0 . 7 8}$ & $\mathbf{0 . 7 4}$ & $\mathbf{0 . 6 3}$ & $\mathbf{0 . 5 9}$ \\
\hline
\end{tabular}

\section{CONCLUSION}

Cut tuberose flowers have relatively short vase life. Enhancing the vase life of cut flowers is important. Malic acid has some roles in plants, it extends the vase life and postharvest quality of tuberose cut flowers if applied in proper concentration. In the present study, the maximum vase life was observed in flowers held in solution containing 300 ppm malic acid.

The current study proved that malic acid was found to be a superior treatment for tuberose cut inflorescence. Citric acid was found to be good in such characters. The fact that they affect cut flowers of tuberose could make it promising to be used as a combined treatment, which can have a synergistic effect.

\section{REFERENCES}

Abou-Dahab, T.A.M. , A.F.Y E. El-Kady, S.A.M. K. Khenizy and E.F.M. ElEbrashi. (2013). Impact of various pulsing and holding solutions on the quality and longevity of Nephrolepis exaltata (L.) Schott cut foliage under room temperature. Journal of Horticultural Science \& Ornamental Plants, 5 (2): 89-99.

Alaey, M., M. Babalar, R. Naderi and M. Kafi. (2011). Effect of pre- and postharvest salicylic acid treatment on physiochemical attributes in relation to vase life of rose cut flowers. Postharvest Biol. Technol., 61: 91-94.

Allaway, W. (1973). Accumulation of malate in guard cells of Vicia faba during stomatal opening. Planta, 110: 63-70.

Begri, F., E. Hadavi and A. Nabigol. (2014). Positive interaction of ethanol with malic acid in post-harvest physiology of cut spray carnation 'White natila. Journal of Horticultural Research, 22(2): 19-30.

da Silva, J.A. (2003). The Cut Flower: Postharvest Considerations. Journal of Biological Sciences, 3: 406- 442. 
Darandeh, N. and E. Hadavi. (2012). Effect of pre-harvest foliar application of citric acid and malic acid on chlorophyll content and post-harvest vase life of Lilium cv. Brunello. Frontiers in Plant Science: Crop Science and Horticulture, 2(106): 1-3.

Dubios, M., K. Gilles, J. Hamlton, P. Rebers, and F. Smith. (1956). Colourimetric method for determination of sugars and related substances. Analytical Chemistry, 28(3): 350- 356.

Eidyan, B., E. Hadavi, and N. Moalemi. (2014). Pre-harvest foliar application of iron sulfate and citric acid combined with urea fertigation affects growth and vase life of tuberose (Polianthes tuberosa L.) 'PorPar'. Horticulture Environment and Biotechnology, 55(1): 9-13.

Ghazijahani, N., E. Hadavi and B. Jeong. (2014). Foliar sprays of citric acid and salicylic acid alter the pattern of root acquisition of some minerals in sweet basil (Ocimum basilicum L.). Front Plant Sci., 5: 1-7.

GOEIC. (1988). Quality specifications of medicinal plants and aromatic oils and flowers exported. Ministry of Trade, Industry and Investment. General Organization for Export and Import Control. p.49 - 50.

He, S., D.C. Joyce, D.E. Irving and J.D. Faragher. (2006). Stem end blockage in cut Grevillea 'Crimson Yul-lo' in inflorescences. Postharvest Biol. Technol., 41: 78-84.

Ibrahim, M.A. (2013). Physiology Vegetable Plants. El-Maref facility, Alexandria, Egypt. Pp. 302.

Jamshidi, M., E. Hadavi and R. Naderi. (2012). Effects of salicylic acid and malic acid on vase life and bacterial and yeast populations of preservative solution in cut Gerbera flowers. Intl. J. Agri. Sci., 2(8): 671674.

Jowkar, M.M. and H. Salehi. (2005). Effects of different preservative solution on the vase life of cut tuberose flowers at usual home conditons. Acta Horticulturae, Proc. VIII ${ }^{\text {th }}$ IS Postharvest Phys. Ornamentals, 411- 416.

Kazemi, M., M. Aran and S. Zamani. (2011). Extending the vase life of lisianthus (Eustoma grandiflorum Mariachii. cv. blue) with different preservatives. Am. J. Plant Physiol., 6: 167-175.

Kazemi, M., E. Hadavi and J. Hekmati. (2012). Effect of salicylic acid, malic acid, citric acid and sucrose on antioxidant activity, membrane stability and ACC-Oxidase activity in relation to vase life of carnation cut flowers. Journal of Agricultural Technology, 8(6): 2053-2063.

Kazemi, M., E. Hadavi and P. Moradi. (2010). The effect of malic acid on the bacteria populations of cut flowers of carnations vase solution. World Appl. Sci. J., 10(7): 737-740.

Lü, P., J. Cao, S. He, J. Liu, H. Li, G. Cheng, Y. Ding and D.C. Joyce. (2010). Nano-silver pulse treatments improve water relations of cut rose cV. Movie Star flowers. Postharvest Biol. Technol. 57: 196-202.

Nowak, J. and R. M. Rudnicki. (1990). Postharvest handling and storage of cut flowers florist, greens and potted plants. Timber Press. p. 210.

Reid, M. S. and M. J. Wu. (1992). Ethylene and flower senescence. Plant Growth Regulation, 11, 373.

Snedecor, G. and W. Cochran. (1967). Statistical Methods. Sixth Edition. lowa State Univ. Press, Ames, 2003. lowa, USA. 
Taha, A. M. (2005). Effect of concentration and application method of ascorbic acid, thiamine and tryptophan on the growth of tuberose plant. M.Sc., Faculty of Agriculture, Alexandria University.

Talebi, M, E. Hadavi and N. Jaafari. (2014). . Foliar sprays of citric acid and malic acid modify growth, flowering, and root to shoot ratio of gazania (Gazania rigens L.): Adv. Agric. Article ID 147278, 1-6.

Van Doorn, W. G. (1997). Water relations of cut flowers. Hortic. Rev. 18: 1-85.

van Meeteren, U. (1978). Water relation and keeping quality of cut gerbera flowers. The cause of stem break. Sci. Hortic., 8: 65-74.

Waithaka, K., M. Reid and L. Dodge. (2001). Cold storage and flower keeping quality of cut tuberose (Polianthes tuberosa L.). Journal of Horticultural Science and Biotechnology,76 (3):271-275.

Williamson V. G., J. D. Faragher, S. Parsons, P. Franz. (2002). Inhibiting the postharvest wound response in wildflowers. Rural Industries Research and Development Corporation (RIRDC), Publication No. 02/114.

Willis, R., B. McGlasson, D. Graham and D. Joyce. (1981). Post-harvest an introduction to the physiology and handling of fruit, vegetables and ornamentals. CAB International. Walling ford Oxon. OX 108 DE.UK.

Yadava, U. (1986). A rapid and non destructive method to determine chlorophyll in intact leaves. Hort. Sci., 21(6): 1449-1450.

Zamani, S., E. hadavi, M. Kazemi and J. Hekmati. (2011). Effect of some chemical treatments on keeping quality and vase life of chrysanthemum cut flowers. World Applied Sciences Journal, 12 (11): 1962-1966.

Zeiger, E. (1983). The biology of stomatal guard cells. Annual Review of Plant Physiology, 34: 441-474.

\section{الملخص العزبي \\ تأثير معاملات ما قبل الحصاد عن طريق الرش بحمض الستريك وحمض الماليك والتربتوفان على التمو والإزهار وحياة ما بعد الحصاد لتباتات التبروز (ب) تأثير معاملات ما قبل الحصاد على عمر الزهزة بعد الحصاد \\ نادر أحمد الشنهورى' ، أشرف مصطفى شحاتة' ، رحاب أحمد صفار r \\ ' فرع بحوث الحدائق النباتية بأنطونيادس - معهد بحوث البساتين - مركز البحوث الزراعية - الإسكندرية

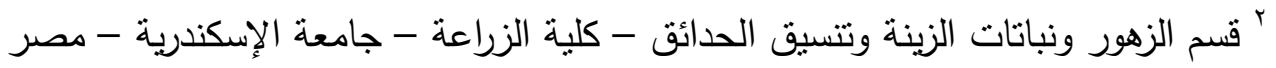 \\ "فرع بحوث نباتات الزينة بأنطونيادس - معهد بحوث البساتين - مركز البحوث الزراعية - الإسكندرية}

يعتبر التبروز احد أشهر أنواع أبصال الزينة المزهرة المستخدمة لجمالها والطلب التجارى عليها، وذلك على الرغم من أن هذه النورات تذبل سريعا فى الفازات داخل المنازل. وللتغلب على هذه الظاهرة نم إجراء تجربة لتقييم وأختبار المعاملة المناسبة لرش النباتات قبل الحصاد والتى قد تعطى أطول عمر للأزهار بعد الحصاد. تم أستخدام ثلاث

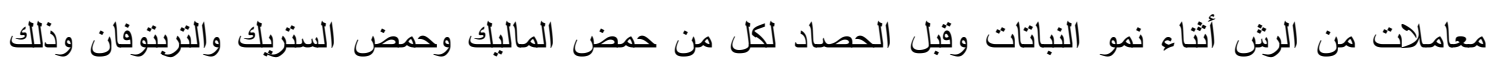




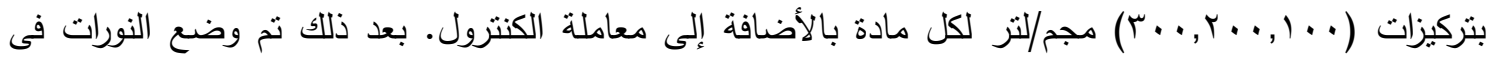

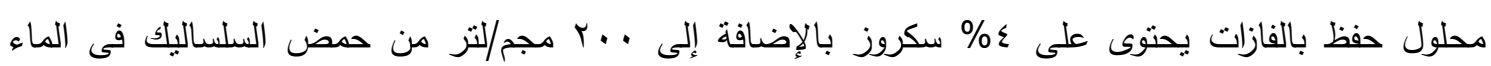
المقطر . تثير النتائج لتقوق حمض الماليك فى كل القياسات الماخوذة بعد الحصاد وخاصة عمر النورات بالأيام

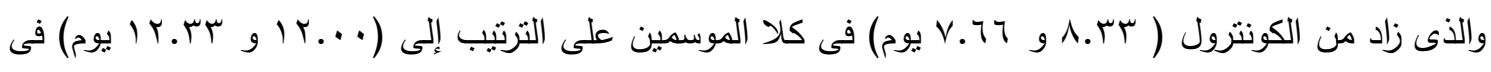
كلا الموسمين على الترتيب ـ كذلك أعطى حض الماليك أعلى محتوى من الكلوروفيل والكربوهيدرات فى نورات التبروز مقارنة بالكنترول. 
